\title{
Small Pheochromocytomas: Clinical, Diagnostic and Perioperative Issues of Disease
}

\author{
Cherenko SM*, Larin OS, Tovkai OA \\ Department of Endocrine Surgery of Ukrainian Research Center for Endocrine Surgery, Ukraine
}

Submission: May 09, 2018; Published: June 26, 2018

*Corresponding author: Sergii Cherenko, Proffessor, Chief of Endocrine Surgery Department, Ukrainian Research Center for Endocrine Surgery, Transplantation of Endocrine Organs and Tissues of Public Health Ministry, 13a, Klovsky uzviz, 01021, Kyiv, Ukraine,

Email: sergmakar5@gmail.com

\begin{abstract}
Small Pheochromocytomas: Clinical, Diagnostic and Perioperative Issues of Disease

Introduction: Pheochromocytoma (P) is considered as relatively rare adrenal tumor with clinical manifestation after reaching the size of 4-6cm. Meanwhile, it's supposing that small P can be not rare found within different diagnostic imagination. Some of these, being clinically silent, can cause serious cardio-vascular risk undergoing unrelated medical procedures. We compared clinical course, peculiarities of diagnostics and treatment of small P (less than $3 \mathrm{~cm}$ ) and bigger P on the basement of own clinical experience among patients underwent adrenalectomy on proven or suspected $P$.
\end{abstract}

Material and methods: Group of small P was comprised by 14 patients aged from 21 to 62 years with mean size of tumor 23mm (range: 4-29mm). Control group consisted of 35 patients corresponded on age (23-75 years) with mean P diameter of 56mm (range: $30-127 \mathrm{~mm}$ ). Small P comprised 8\% of all 175 patients with P operated on during the last 19 years in endocrine surgery hospital from the whole group of 967 adrenalectomies. Prevalence of women and right side lesions characterized both groups.

Discussion: Principal differences between groups were less prominent clinical activity (any symptoms were detected in half of small P) with less level of catecholamines and metanefrines in lab examination of serum and urea of small P patients. Computed tomography was often the first but not targeted diagnostic step. Silent clinical course was the main reason that small $\mathrm{P}$ have been discovered predominantly incidentally with no blockage of alpha-adrenergic receptors before surgery in 6 of 14 patients. Most of them had a critical elevation of blood pressure during operation ( $43 \%$ against $9 \%$ in control group; $\mathrm{p}<0.05$ ). Despite small size and mild catecholamine excess in small P group, 4 from 14 patients (29\%) experienced episodes of potentially harmful hypertensive crisis during unrelated medical procedures in the past. All small P were treated successfully by laparoscopic adrenalectomy. Most of patients became free from hypertension.

Conclusion: Small P may carry actual risk of unexpected hypertensive crisis during any unrelated medical procedures. The clinical course of small $\mathrm{P}$ is hidden in half of patients and laboratory investigations are interfered with mild elevation of biochemical markers. Laparoscopic adrenalectomy is safe mode of treatment of small $\mathrm{P}$ in case of adequate preparation.

Keywords: Pheochromocytoma; Small size; Diagnostics; Peculiarities; Laparoscopic adrenalectomy

\section{Introduction}

Pheochromocytoma (P) is considered as relatively rare adrenal tumor which typically demonstrates clinical manifestation after reaching the size of $4-6 \mathrm{~cm}$. The rate of P among adrenal incidentalomas is about $5 \%$, and on autopsy among died from all causes 1:1000 [1]. Meanwhile, it's supposing that small $\mathrm{P}$ can be not rare found within different diagnostic imagination. Some of these, being clinically silent, can cause serious cardiovascular risk undergoing unrelated medical procedures [2].

Half of $\mathrm{P}$ are discovered only at autopsy despite most of them demonstrated bright clinical symptoms [2,3]. From this point of view the case of $34^{\text {th }}$ USA President Dwight David Eisenhower, whose diagnosis of small $\mathrm{P}$ was revealed only postmortem, is a very illustrative example. He suffered from poor controlled arterial hypertension for a long time and sustained 4 myocardial infarction [4].

Purpose

To compare clinical course, peculiarities of diagnostics and treatment of small $\mathrm{P}$ (less than $3 \mathrm{~cm}$ ) and bigger $\mathrm{P}$ on the basement of own clinical experience among patients underwent adrenalectomy due proven or suspected diagnosis.

\section{Material and Methods}

There was a retrospective study with randomized historical control group. All together during 1.01.1997-1.08.2016 years 
in Department of Endocrine Surgery of Ukrainian Research Center for Endocrine Surgery of Public Health Ministry 967 adrenalectomies have been performed. Tumors arisen from adrenal medulla comprised $18.1 \%$ (175 cases). Patients were aged from 8 to 75 years with female prevalence (74.3\%). Size of $\mathrm{P}$ mostly exceeds $30 \mathrm{~mm}$ ranged from $3.8 \mathrm{~mm}$ to $127 \mathrm{~mm}$ (mean $47.99 \pm 2.93 \mathrm{~mm}$ ). Adrenalectomy was performed initially through open conventional lumbotomy, but during last decade predominantly by laparoscopic methodic $(71.4 \%$ among all cases).

The group of small $\mathrm{P}$ was comprised by 14 patients aged from 21 to 62 years with mean size of tumor $23 \mathrm{~mm}$ (range: 4-29mm). Control group consisted of 35 patients corresponded on age (23-75 years) with mean tumor diameter of $56 \mathrm{~mm}$ (range: $30-127 \mathrm{~mm}$ ). Small P comprised $8 \%$ of all 175 patients with $\mathrm{P}$ operated on during the last 19 years in endocrine surgery hospital from the whole group of 967 adrenalectomies. Prevalence of women and right side lesions characterized both groups. We excluded from both groups all cases of malignant $\mathrm{P}$, family forms, bilateral P, children and pregnant.

After laboratory confirmation of diagnosis patients were prepared by alpha-adrenoblockers till stable normalization of BP. Computed tomography was the main method of visualization (in most cases - on «Toshiba Aquilion 64» CT). Laparoscopic adrenalectomy was performed by well known traditional methodic of M. Gagner [7] with authors modification [8]. Statistics for compared groups of study based on paired " $t$ " test. Difference considered significant if $\mathrm{P}$ was less than 0.05 .

\section{Results and Discussion}

Typical presentation of $\mathrm{P}$ in group of small $\mathrm{P}$ was the incidentally discovered on CT adrenal tumor of high native attenuation (mean - +31.06 $\pm 3.52 \mathrm{HU}$ ) - Figure 1. Macroscopically small P looks like homogenous solid tumor of grey or grey-cherry color defined by thin capsule (Figure 2). Clinical and laboratory data of studied groups are presented in Table 1.

Table 1: Main clinical and laboratory features of studied groups of $P$.

\begin{tabular}{|c|c|c|c|}
\hline Compared features: & Small Pheo $(n=14)$ & Bigger Pheo $(n=35)$ & $\mathbf{p}$ \\
\hline \multirow{3}{*}{ Size; mm } & $<30$ & $\geq 30$ & \multirow{3}{*}{$<0.05$} \\
\hline & Mean $\emptyset-22.96 \pm 1.30$ & Mean $\emptyset-56.03 \pm 3.22$ & \\
\hline & $(3.8-29.9)$ & $(30-127)$ & \\
\hline \multirow{2}{*}{ Age: mean (range); years } & $42.12 \pm 3.53$ & $44.91 \pm 1.26$ & \multirow{2}{*}{$>0.05$} \\
\hline & $(21-62)$ & $(23-75)$ & \\
\hline Sex: female/male; \% & $71.43 / 28.57$ & $68.57 / 31.43$ & $>0.05$ \\
\hline \multirow{3}{*}{$\begin{array}{l}\text { Clinical diagnosis established: } \\
\text { before operation/after operation } \\
\text { (n) }\end{array}$} & & & \multirow{3}{*}{$<0.05$} \\
\hline & $6(42.9 \%) /$ & $34(97.1 \%) /$ & \\
\hline & $8(57.1 \%)$ & $1(2.9 \%)$ & \\
\hline \multirow{2}{*}{$\begin{array}{l}\text { Tumor visualization: incidentally/ } \\
\text { based on clinical suspicion (n) }\end{array}$} & $10(71.4 \%) /$ & $7(20.0 \%) /$ & \multirow{2}{*}{$<0.05$} \\
\hline & $4(28.6 \%)$ & $28(80.0 \%)$ & \\
\hline \multirow{2}{*}{ Arterial hypertension: Yes/No (n) } & $8(57.1 \%) /$ & $34(97.1 \%) /$ & \multirow{2}{*}{$<0.05$} \\
\hline & $6(42.9 \%)$ & $1(2.9 \%)$ & \\
\hline \multirow{2}{*}{$\begin{array}{l}\text { Previous cardio-vascular } \\
\text { complications: Yes/No (n) }\end{array}$} & $2(14.3 \%) /$ & $12(34.3 \%) /$ & \multirow{2}{*}{$>0.05$} \\
\hline & $12(85.7 \%)$ & $23(65.7 \%)$ & \\
\hline \multirow{7}{*}{$\begin{array}{l}\text { Presented with clinical symptoms } \\
\begin{array}{cc}\text { (n): } \\
-\quad \text { tachycardia } \\
\text { - palpitations } \\
\text { - } \text { headache } \\
-\quad \text { face hyperemia } \\
\text { - } \quad \text { sweetening } \\
\text { - fatigue, dizziness syncope }\end{array}\end{array}$} & $6(42.9 \%)$ & $33(94.3 \%)$ & \multirow{7}{*}{$>0.05$} \\
\hline & $3(21.4 \%)$ & $28(80.0 \%)$ & \\
\hline & $5(35.7 \%)$ & $32(91.4 \%)$ & \\
\hline & $0(0 \%)$ & $18(51.4 \%)$ & \\
\hline & $0(0 \%)$ & $16(45.7 \%)$ & \\
\hline & $0(0 \%)$ & $31(88.6 \%)$ & \\
\hline & & & \\
\hline \multirow{2}{*}{$\begin{array}{c}\text { Hypertensive crisis during } \\
\text { unrelated medical procedures: } \\
\text { Yes/No (n) }\end{array}$} & $4(28.6 \%) /$ & $21(60.0 \%) /$ & \multirow[b]{2}{*}{$>0.05$} \\
\hline & $10(71.4 \%)$ & $14(40.0 \%)$ & \\
\hline \multirow{3}{*}{$\begin{array}{c}\text { Predominantly elevated: } \\
\text { metanefrines/normetanefrines/ } \\
\text { other (n) }\end{array}$} & $7(50.0 \%) /$ & $29(82.9 \%) /$ & \multirow{3}{*}{$>0.05$} \\
\hline & $2(14.3 \%) /$ & $2(5.7 \%) /$ & \\
\hline & $1(7.1 \%)$ & $1(2.9 \%)$ & \\
\hline
\end{tabular}




\section{Journal of Endocrinology and Thyroid Research}

\begin{tabular}{|c|c|c|c|}
\hline \multirow{2}{*}{$\begin{array}{c}\text { Grade of hormonal elevation: } \\
\text { normal / 1,5-2 times / 2-4 times } \\
\text { / >4 times }\end{array}$} & $4(28.6 \%) /$ & $3(8.6 \%) /$ & $>0.05$ \\
\cline { 2 - 4 } & $5(35.7 \%) /$ & $10(28.6 \%) /$ & $>0.05$ \\
\cline { 2 - 4 } & $4(28.6 \%) /$ & $14(40.0 \%) /$ & $>0.05$ \\
\hline $\begin{array}{c}\text { Signs of Pheo on imagination: } \\
\text { suspicion / apparent / adenoma- } \\
\text { like }\end{array}$ & $0(0 \%)$ & $8(22.8 \%)$ & $>0.05$ \\
\cline { 2 - 4 } $\begin{array}{c}\text { Alpha-adreno blockage before } \\
\text { operation (n) }\end{array}$ & $3(35.7 \%) /$ & $2(5.7 \%) /$ & $>0.05$ \\
\hline $\begin{array}{c}\text { Hemodynamic disturbance during } \\
\text { operation, episodes of BP>180mm }\end{array}$ & $3(21.4 \%)$ & $34(94.3 \%) /$ & $>0.05$ \\
\hline \begin{tabular}{c} 
Hg.: Yes/No (n) \\
\cline { 2 - 4 } $\begin{array}{c}\text { Term of postoperative follow-up, } \\
\text { mean (diapason); years }\end{array}$
\end{tabular} & $6(42.9 \%) /$ & $3(8.6 \%) /$ & $<0.05$ \\
\hline $\begin{array}{c}\text { Withdraw of antihypertensive } \\
\text { drugs after operation: Yes/No (n) }\end{array}$ & $2.23(1-13)$ & $32(91.4 \%)$ & $<0.05$ \\
\hline $\begin{array}{c}\text { Normalization of BP after } \\
\text { operation: Yes/No (n) }\end{array}$ & 2 -Jun & $4.89(1-13)$ & $>0.05$ \\
\hline
\end{tabular}

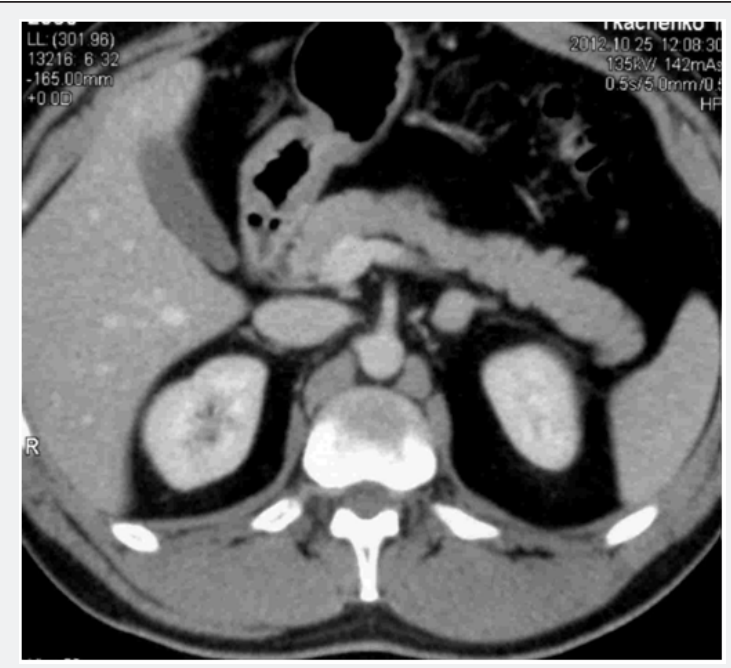

Figure 1: Small P (14mm) of left adrenal gland on non-contrast CT.

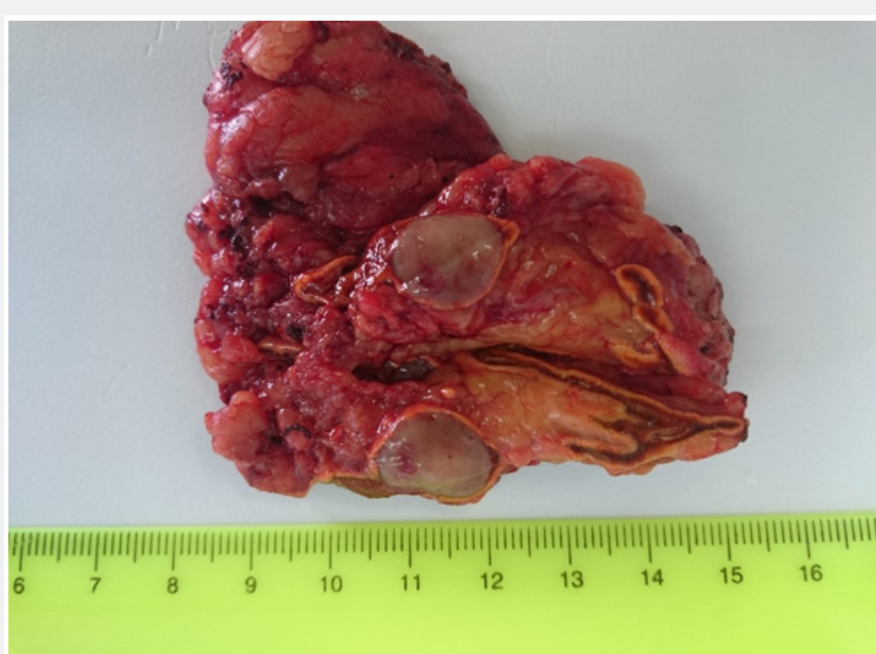

Figure 2: Macroscopic view of removed small $P$ within left adrenal gland. 
The less prominent clinical activity (any symptoms were detected in half of small P) with less level of catecholamines and metanefrines in lab examination of serum and urea of small $P$ patients represented the principal difference between groups. Computed tomography was often the first but not targeted diagnostic step. Silent clinical course was the main reason that small $\mathrm{P}$ have been discovered predominantly incidentally with no blockage of alpha-adrenergic receptors before surgery in 6 of 14 patients. Most of them had a critical elevation of blood pressure during operation (43\% against $9 \%$ in control group).

Despite small size and mild catecholamine excess in group of small P, 4 from 14 patients (29\%) experienced some episodes of potentially harmful hypertensive crisis during unrelated medical procedures in the past. All small P were treated with successful laparoscopic adrenalectomy. Most of patients became free from arterial hypertension.

\section{Discussion}

Our study confirmed opinion of some authors that even small P can bring significant risk for patients in case of stressful situation or unrelated medical procedures [5,6]. Despite existing information about significant rate of "hidden" $\mathrm{P}$ in population $[1,9]$, targeted screening of P among patients with elevated BP or sympathetic crisis is not recommended routinely. Yu $\mathrm{R}$ et al. [5] supposed that small P could carry the $17 \%$ cardio-vascular risk in case of unrelated surgical or dentistry manipulation, that is equal to $\mathrm{P}$ of regular size. We found two fold differences in such risk for small and bigger P (29\% against 69\%), but it even more than found previous authors and allow us strongly recommend surgical operation for all such patients, as it sounds from other investigators $[5,6]$. Some authors recommend adrenal venous sampling with glucagon stimulation test in patients with negative visualization but clinical suspicion to catecholamine producing tumor, that prove presence of $\mathrm{P}$ in 36 from 41 patients[6]. Mere than half of those patients became normotensive after operation. We also observed normalization of BP in $3 / 4$ of operated patients within first months after adrenalectomy. Laparoscopic methodic of adrenalectomy for patients with $\mathrm{P}$ is well recognized type of surgery all around the world $[1,7,8]$, all the more for small tumors, and we confirm it one more time on our clinical series [9].

\section{Conclusion}

Pheochromocytomas of size less than $3 \mathrm{~cm}$ is not exclusive catecholamine producing tumors and comprise $8 \%$ of operated on P in large clinical series. Small P may carry actual risk of unexpected hypertensive crisis during any unrelated medical procedures. The clinical course of small $\mathrm{P}$ is hidden in half of patients and laboratory investigations are interfered with mild elevation of biochemical markers. Laparoscopic adrenalectomy is reliable and safe mode of treatment of small $\mathrm{P}$ in case of adequate preparation with alpha-blockers.

\section{Notice}

This study was presented on $7^{\text {th }}$ Symposium of European Society of Endocrine Surgeons, 6-8 April, 2017, Oxford, UK.

\section{References}

1. Lenders JWM, Duh QY, Eisenhofer G, Gimenez-Roqueplo AP, Grebe SKG, et al. (2014) Pheochromocytoma and Paraganglioma: An Endocrine Society Clinical Practice Guideline. J Clin Endocrinol Metab 99(6): 1915-1942.

2. Pacak K, Eisenhofer G, Ahlman H, Bornstein SR, Gimenez-Roqueplo AP, et al. (2007) Pheochromocytoma: recommendations for clinical practice from the First International Symposium (October 2005). Nat Clin Pract Endocrinol Metab 3(2): 92-102.

3. Goldstein RE, O'Neill JA, Holcomb GW, Morgan WM, Neblett WW, et al. (1999) Clinical experience over 48 years with pheochromocytoma. Ann Surg 229(6): 755-764.

4. Messerli FH, Loughlin KR, Messerli AW, Welch WR (2007) The president and the pheochromocytoma. Am J Cardiol 99(9): 1325-1329.

5. Yu R, Pitts A, Wei M (2012) Small Pheochromocytomas: Significance, Diagnosis, and Outcome. J Clin Hypertens (Greenwich) 14(5): 307-315.

6. Mercado-Asis LB, Tingcungco AG, Bolong DT, Lopez RA, Caguioa EV, et al. (2011) Diagnosis of Small Adrenal Pheochromocytomas by Adrenal Venous Sampling with Glucagon Stimulation Test. Int J Endocriol Metab 9(2): 323-329.

7. Gagner M, Lacroix A, Bolté E (1992) Laparoscopic adrenalectomy in Cushing's syndrome and pheochromocytoma. N Engl J Med 327(14): 1033-1039.

8. Cherenko SM, Larin OS, Tovkai OA (2016) Adjustment of Endoscopic Ports Position for Laparoscopic Adrenalectomy Considering Age, Clinical and Anatomical Peculiarities of Patients. Ukr J Minimally Invasive Endosc Surg 20(3): 26-30.

9. Yamakita N, Saitoh M, Mercado-Asis LB, Kitada M, Morita H, et al. (1990) Asymptomatic adrenal tumor; 386 cases in Japan including our 7 cases. Endocrinol Jpn 37(5): 671-684. 
(C) (i) This work is licensed under Creative Commons Attribution 4.0 Licens DOI: 10.19080/JETR.2018.03.555619
Your next submission with Juniper Publishers will reach you the below assets

- Quality Editorial service

- Swift Peer Review

- Reprints availability

- E-prints Service

- Manuscript Podcast for convenient understanding

- Global attainment for your research

- Manuscript accessibility in different formats ( Pdf, E-pub, Full Text, Audio)

- Unceasing customer service

Track the below URL for one-step submission https://juniperpublishers.com/online-submission.php 